\title{
The Role of Knowledge Management as a Mediating Variable of Customs Electronic Business Impact on the Institutional Performance of the Customs Authority in the Arab Republic of Egypt
}

\author{
Ahmed Abdel-Raof Eid, Mohamed Abdel Salam Ragheb, Ayman Ahmed Ragab \\ The Arab Academy for Science and Technology \& Maritime Transport, Alexandria, Egypt \\ Email: ahmedabdelraofaid@gmail.com
}

How to cite this paper: Eid, A.A.-R., Ragheb, M.A.S. and Ragab, A.A. (2021) The Role of Knowledge Management as a Mediating Variable of Customs Electronic Business Impact on the Institutional Performance of the Customs Authority in the Arab Republic of Egypt. Open Access Library Journal, 8: e8109.

https://doi.org/10.4236/oalib.1108109

Received: October 22, 2021

Accepted: October 26, 2021

Published: October 29, 2021

Copyright (c) 2021 by author(s) and Open Access Library Inc.

This work is licensed under the Creative Commons Attribution International License (CC BY 4.0).

http://creativecommons.org/licenses/by/4.0/

\begin{abstract}
The study aimed to investigate the impact of electronic customs business on the institutional performance of the Customs Authority in the Arab Republic of Egypt through knowledge management as a mediator variable. The researcher adopted the analytical quantitative approach, and relied on the questionnaire as the main tool for the study, where (500) questionnaires were distributed, and (410) were returned, with a respond rate of (82\%). The data were analyzed using a set of statistical methods using SPSS-V23 and AMOS-V23. The study reached a set of results, the most important of which is: there is a significant and statistically significant effect of electronic customs work on the institutional performance of the Customs Authority in the Arab Republic of Egypt and on knowledge management. Based on the results of the study, the study concluded with a set of recommendations, the most important of which is: the importance of applying electronic business through all facilities of the Customs Authority in particular and all government service institutions in general in order to improve the quality of service provided and improve the performance of government institutions.
\end{abstract}

\section{Subject Areas \\ Information Science}

\section{Keywords}

Electronic Business, Custom Authority, Knowledge Management, Institutional Performance 


\section{Introduction}

The customs policy is considered one of the most important financial policy tools aimed to achieve economic and social goals of all countries alike [1], and the customs authorities are one of the basic elements of the international trade cycle. It plays an important role in encouraging local industries, raising the rate of economic development, facilitating trade, contributing to the protection of society and promoting economic development [2]. In addition, customs revenue is an important resource of the sovereign resources of the state.

Despite the importance of the customs sector in Egypt, according to a World Bank report, Egypt ranks 171st in the world in the cross-border trade index out of 191 countries covered by the index. The Egyptian customs administration process suffers from many difficulties and many shortcomings, the most important of which is the inadequacy of the current customs law for global practices in the field of international trade, and the weakness of the efficiency of the current customs procedures and their low effectiveness in achieving their objectives, which leads to an increase in documentary cycle for customs clearance, and the length of time required for customs clearance, lack of technological infrastructure and the authority's information system, and the weakness of the financial capabilities to facilitate and speed the goods clearance [3].

Modern technologies have affected almost every aspect of human life, leading to radical changes in the field of business, and institutions in all their forms, governmental or private, seek to benefit from the massive and rapid developments in the field of information and communication technology and move forward towards digital transformation and transform institutions into what is called In "Electronic Business" [4].

Many countries have taken great steps towards electronic customs systems, or digital customs, where the term digital customs refer to any automated or electronic activity, which contributes to the effectiveness, efficiency and coordination of customs activities, such as automated customs clearance systems [5]. The new era of digital customs has changed the way customs work and transformed the customs landscape. It contributes to enhancing the ability of customs administrations to communicate, receive and exchange information, coordinate border activities, cooperate in law enforcement procedures, and enhance transparency [6].

Facing the rapid changes in the business environment requires a new direction of work that responds and keeps pace with these challenges and changes. Accordingly, and after it became necessary to develop the Customs Authority [7], the current study seeks to investigate the impact of electronic business customs on institutional performance of the Customs Authority in the Arab Republic of Egypt through knowledge management as a mediator variable.

In the current paper, we will discuss the literature review, research methodology which includes research model, research tool, hypotheses testing, and finally the paper ends with recommendations depending on results. 


\section{Literature Review}

\section{E-Business:}

The use of information and communication technology (ICT) in business management through the technologies and capabilities of the Internet, not only buying and selling but also customer service and cooperation with business partners. E-business methods enable companies to connect their internal and external data processing and information exchange systems more efficiently and flexibly, work more closely with suppliers and partners, and better meet the needs and expectations of their customers [8].

\section{E-Customs:}

Using information technology to carry out customs work using electronic communication channels so as to replace customs procedures with manual methods and paperwork, thus creating a more efficient and modern customs environment [4].

\section{Dimensions of customs e-business:}

The dimensions of customs electronic business are as follows [9].

Electronic Infrastructure:

It means the data, software, hardware, networks and implementation systems that serve the work of the Customs Authority [10].

\section{E-Business Systems:}

It means all the electronic implementations used in the Customs Authority that contribute to coordinating the activities of the different departments, the decisions and the knowledge present in the different organizational processes [11].

\section{Customs Information Systems:}

It means the elements, information, people, procedures and equipment that are interrelated and interact, which work together in a coordinated manner through a set of organized processes and present the results in different forms to support the decision and improve the performance of the Customs Authority [12].

Electronic customs services:

It means the shift from paper customs procedures to electronic platforms via the Internet and modern technologies [13].

\section{Customs risk analysis management systems}

According to the World Customs Organization (WCO), customs risk management is defined as the systematic implementation of management procedures and practices that provide Customs with the information needed to handle movements or shipments that indicate a risk. The implementation of risk management is included as one of the seven basic principles included in trade facilitation, and risk management is the methodology of the mechanism of implementing all necessary and important strategies to reduce exposure to customs risks as it depends on the evaluation of individuals, goods and means of shipping and classification according to certain mechanisms and then how to deal with those risks Variation of levels of examination and scrutiny.

Customs risks include: potential non-compliance with customs policies such 
as licensing obligations, customs assessment and assessment provisions, tax and customs exemption regimes, rules of origin, security regulation, trade restrictions, and international trade facilitation obstacles and violations [14].

\section{Knowledge management}

The concept of "knowledge management" means the processes carried out by organizations to acquire and acquire knowledge in order to help organizations solve problems and improve the decision-making process as well as the organization's achievement of its objectives [15]. The "knowledge management" system includes all the interacting and interrelated elements that ensure control and control of the knowledge of the organization, and knowledge management includes: the processes of acquiring, preserving, storing, employing and disseminating knowledge [16].

\section{Research Model}

The proposed comprehensive conceptual model is presented in Figure 1. The diagram below shows that there is one independent variable for the study of electronic business customs. There is one dependent variable institutional performance of the Customs Authority and. There is one mediating variable Knowledge Management. It shows the direct and indirect affect between variables. From the above discussion, the research model is as shown in Figure 1 below.

\section{Research Questions and Hypotheses}

The attempt of this study was to determine:

Q1: if there is an effect of electronic business customs on institutional performance of the Customs Authority in the Arab Republic of Egypt.

Q2: if there is an effect of electronic business customs on knowledge management of the Customs Authority in the Arab Republic of Egypt.

Q3: if there is an effect of knowledge management of the Customs Authority on institutional performance of the Customs Authority in the Arab Republic of Egypt.

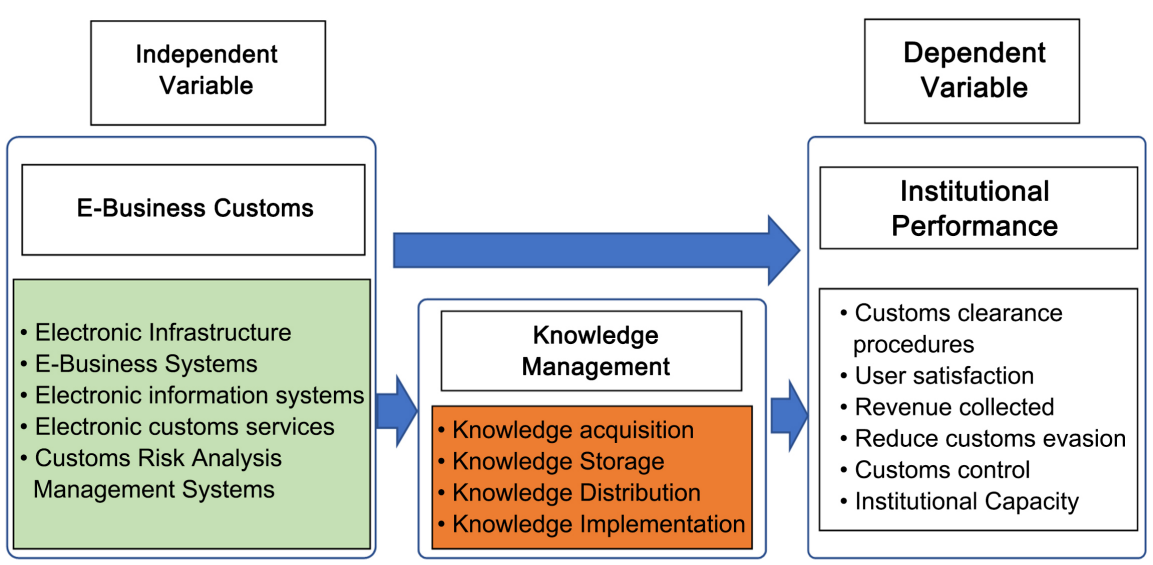

Figure 1. The research model of this study (Source: by researcher depending on previous studies). 
Q4: if there is an effect of electronic business customs on institutional performance of the Customs Authority in the Arab Republic of Egypt through knowledge management as a mediator variable

The following hypotheses were developed to decide if there is a significant correlation between electronic business customs and institutional performance.

- H1 There is a significant relationship and effect of adoption of electronic business customs strategies on institutional performance of the Customs Authority of the Arab Republic of Egypt.

- H2 There is a significant relationship and effect of adoption of electronic business customs strategies on knowledge management of the Customs Authority of the Arab Republic of Egypt.

- H3 There is a significant relationship and effect of a knowledge management on the institutional performance of the Customs Authority of the Arab Republic of Egypt.

- H4 There is a significant relationship and effect of adoption of electronic business customs strategies and the institutional performance of the Customs Authority of the Arab Republic of Egypt through knowledge management as a mediating variable.

\section{Research Methodology}

The researcher adopted the analytical quantitative approach, and relied on the questionnaire as the main tool for the study.

The population of the study included all employees at Customs Authority in the Arab Republic of Egypt, The number of samples obtained by (500) employees, questionnaires was distributed, and (410) were returned, with a respond rate of $(82 \%)$. The data were analyzed using a set of statistical methods using SPSS-V23 and AMOS-V23.

\section{Study Tool}

The study relied on the questionnaire as the main study tool. A questionnaire was prepared on "impact of electronic customs business on the institutional performance of the Customs Authority in the Arab Republic of Egypt through knowledge management as a mediator variable".

The questionnaire consists of:

1) Part 1: Demographic data.

2) Part Two: variables dimensions and items.

The present study has investigated electronic customs business as an independent variable. The researcher will depend on the scale developed by Al-A'wasa, 2017; which has been divided into five elements. With 37-item, There were eight items measuring Electronic Infrastructure, seven items measuring E-Business Systems, eight items measuring Electronic information systems, six items measuring Electronic customs services and eight items measuring Customs Risk Analysis Management Systems. 
Also the present study has investigated Knowledge Management as mediating variable. The researcher will depend on the scale developed by Al Fares, 2010; which has been divided into four elements. With 27-item, There were eight items measuring Knowledge acquisition, five items measuring Knowledge Storage, six items measuring Knowledge Distribution and eight items measuring Knowledge Implementation.

Also the present study has investigated Institutional Performance as dependent variable. The researcher will depend on the scale developed by Al-A'wasa, 2017; which has been divided into six elements. With 26-item, There were four items measuring Customs clearance procedures, four items measuring User satisfaction, four items measuring Revenue collected, four items measuring Reduce customs evasion, four items measuring Customs control, and four items measuring Institutional Capacity.

Responses are categorized using a 5-point Likert Scale for each statement, ranging from 1) "very ineffective", 2) "ineffective", 3) "neither effective nor ineffective", 4) "effective", and 5) "very effective". The informant should select the answer that suits his choice, where 5) indicates full agreement while 1) indicates full disagreement, with neutral degrees in-between.

The following Table 1 summarizes numbers of items for each dimension of each variable.

Table 1. Questionnaire source and No of items.

\begin{tabular}{|c|c|c|c|c|}
\hline & Variable & Dimensions & No of Item & Source \\
\hline 1 & \multirow{3}{*}{ Independent Variable } & Electronic Infrastructure & 8 & \multirow{5}{*}{$\begin{array}{l}\text { Al-A'wasa, } \\
2017\end{array}$} \\
\hline 2 & & E-Business Systems & 7 & \\
\hline 3 & & Electronic information systems & 8 & \\
\hline 4 & \multirow{2}{*}{$\begin{array}{l}\text { Electronic Business } \\
\text { Customs }\end{array}$} & Electronic customs services & 6 & \\
\hline 5 & & $\begin{array}{l}\text { Customs Risk Analysis } \\
\text { Management Systems }\end{array}$ & 8 & \\
\hline \multicolumn{4}{|c|}{37} & \multirow{6}{*}{$\begin{array}{l}\text { Al Fares, } \\
2010\end{array}$} \\
\hline 6 & \multirow{4}{*}{$\begin{array}{l}\text { Knowledge } \\
\text { Management }\end{array}$} & Knowledge acquisition & 8 & \\
\hline 7 & & Knowledge Storage & 5 & \\
\hline 8 & & Knowledge Distribution & 6 & \\
\hline \multirow[t]{2}{*}{9} & & Knowledge Implementation & 8 & \\
\hline & 27 & & & \\
\hline 10 & \multirow{3}{*}{ Dependent Variable } & Customs clearance procedures & 4 & \multirow{6}{*}{$\begin{array}{l}\text { Al-A'wasa, } \\
2017\end{array}$} \\
\hline 11 & & User satisfaction & 4 & \\
\hline 12 & & Revenue collected & 4 & \\
\hline 13 & \multirow{3}{*}{$\begin{array}{l}\text { Institutional } \\
\text { Performance }\end{array}$} & Reduce customs evasion & 4 & \\
\hline 14 & & Customs control & 4 & \\
\hline 15 & & Institutional Capacity & 6 & \\
\hline & 26 & & & \\
\hline
\end{tabular}




\section{Evaluating Reliability:}

As shown in Table 2, the reliability of the study questionnaire was verified by Cronbach's Alpha coefficient, and the results showed the Cronbach Alpha coefficient (96.8\%) which is a statistically acceptable level as long as it is greater than (0.6).

\section{Evaluating Validity:}

To test the validity of the questionnaire, the correlation coefficient was calculated between each dimension of the study and the general coefficient of the questionnaire (Table 3).

\section{Hypothesis Testing Results}

\subsection{First Major Hypothesis Test}

There is a significant effect and a statistically significant relationship between the implementation of customs e-business and the institutional performance of the Customs Authority of the Arab Republic of Egypt.

Table 2. Reliability of questionnaire.

\begin{tabular}{|c|c|c|c|}
\hline & Variable & Dimensions & $\begin{array}{c}\text { Cronbach Alpha } \\
\text { coefficient }\end{array}$ \\
\hline 1 & \multirow{6}{*}{$\begin{array}{l}\text { Independent Variable } \\
\text { Electronic Business } \\
\text { Customs }\end{array}$} & Electronic Infrastructure & 88.8 \\
\hline 2 & & E-Business Systems & 89.6 \\
\hline 3 & & Electronic information systems & 90.00 \\
\hline 4 & & Electronic customs services & 86.9 \\
\hline \multirow[t]{2}{*}{5} & & $\begin{array}{l}\text { Customs Risk Analysis } \\
\text { Management Systems }\end{array}$ & 70.00 \\
\hline & & & 95.4 \\
\hline 6 & \multirow{5}{*}{$\begin{array}{c}\text { Mediating Variable } \\
\text { Knowledge } \\
\text { Management }\end{array}$} & Knowledge acquisition & 76.2 \\
\hline 7 & & Knowledge Storage & 85.2 \\
\hline 8 & & Knowledge Distribution & 90.2 \\
\hline \multirow[t]{2}{*}{9} & & Knowledge Implementation & 88.6 \\
\hline & & & 94.6 \\
\hline 10 & \multirow{8}{*}{$\begin{array}{l}\text { Dependent Variable } \\
\text { Institutional } \\
\text { Performance }\end{array}$} & Customs clearance procedures & 68.8 \\
\hline 11 & & User satisfaction & 78.3 \\
\hline 12 & & Revenue collected & 90.1 \\
\hline 13 & & Reduce customs evasion & 85.1 \\
\hline 14 & & Customs control & 64.6 \\
\hline \multirow[t]{3}{*}{15} & & Institutional Capacity & 92.00 \\
\hline & & & 94.4 \\
\hline & & & 96.8 \\
\hline
\end{tabular}


Table 3. Reliability of questionnaire.

\begin{tabular}{|c|c|c|c|c|c|}
\hline & Variable & Dimensions & $\begin{array}{l}\text { No of } \\
\text { Item }\end{array}$ & $\begin{array}{l}\text { Correlation } \\
\text { Coefficients }\end{array}$ & Sig \\
\hline 1 & & Electronic Infrastructure & 8 & $\% 70.2$ & 0.000 \\
\hline 2 & Independent & E-Business Systems & 7 & $\% 78.5$ & 0.000 \\
\hline 3 & Variable & Electronic information systems & 8 & $\% 69.7$ & 0.000 \\
\hline 4 & Electronic Business & Electronic customs services & 6 & $\% 65.7$ & 0.000 \\
\hline \multirow[t]{2}{*}{5} & Customs & $\begin{array}{l}\text { Customs Risk Analysis } \\
\text { Management Systems }\end{array}$ & 8 & $\% 65$ & 0.000 \\
\hline & 37 & & & $\% 62.5$ & 0.000 \\
\hline 6 & \multirow[b]{2}{*}{ Mediating Variable } & Knowledge acquisition & 8 & $\% 83.8$ & 0.000 \\
\hline 7 & & Knowledge Storage & 5 & $\% 73$ & 0.000 \\
\hline 8 & \multirow[t]{2}{*}{$\begin{array}{l}\text { Knowledge } \\
\text { Management }\end{array}$} & Knowledge Distribution & 6 & $\% 79.8$ & 0.000 \\
\hline 9 & & Knowledge Implementation & 8 & $\% 78.1$ & 0.000 \\
\hline & 27 & & & $\% 84.4$ & 0.000 \\
\hline 10 & \multirow[b]{3}{*}{ Dependent Variable } & Customs clearance procedures & 4 & $\% 90.4$ & 0.000 \\
\hline 11 & & User satisfaction & 4 & $\% 61$ & 0.000 \\
\hline 12 & & Revenue collected & 4 & $\% 71$ & 0.000 \\
\hline 13 & $\begin{array}{l}\text { Institutional } \\
\text { Performance }\end{array}$ & Reduce customs evasion & 4 & $\% 37.2$ & 0.028 \\
\hline 14 & & Customs control & 4 & $\% 44.2$ & 0.008 \\
\hline \multirow[t]{2}{*}{15} & & Institutional Capacity & 6 & $\% 42$ & 0.000 \\
\hline & 26 & & & $\% 58.8$ & 0.000 \\
\hline
\end{tabular}

To test the previous hypothesis, the researcher used a multiple regression analysis, as well as calculating the regression coefficients, to test the impact of the adoption of customs e-business on institutional performance, where the regression analysis was conducted through the dimensions of customs e-business (Electronic infrastructure - electronic business systems - electronic information systems - electronic customs services - customs risk analysis management systems) as independent variables and customs institutional performance as a dependent variable.

It is evident from Table 4 that:

- The calculated (F) value of the analysis of variance (ANOVA) 130.94 with a level of statistical significance (Sig) equal to $(0.000)$ i.e. less than 5 , which means the quality of the model and the presence of a significant statistically significant effect of the independent variables on the dependent variable, it means, there is a significant effect of customs electronic business on the institutional performance of customs. 
Table 4. Regression analysis of customs e-business dimensions on customs institutional performance.

\begin{tabular}{cccccc}
\hline & B & Std. Error & Beta & T & Sig. \\
\hline $\begin{array}{c}\text { (Constant) } \\
\text { Electronic Infrastructure }\end{array}$ & 0.109 & 0.046 & 0.148 & 2.356 & 0.019 \\
$\begin{array}{c}\text { E-Business Systems } \\
\text { Electronic information systems }\end{array}$ & 0.135 & 0.061 & 0.181 & 2.224 & 0.027 \\
$\begin{array}{c}\text { Electronic customs services } \\
\text { Customs Risk Analysis }\end{array}$ & 0.182 & 0.053 & 0.241 & 3.422 & 0.001 \\
Management Systems & 0.084 & 0.040 & 0.110 & 2.083 & 0.038 \\
$\quad$ & & & & & \\
ANOVA(F) & 130.94 & (F)Sig & $\mathbf{0 . 0 0 0}$ & $\mathbf{R}^{2}$ & $\mathbf{0 . 6 1 8}$ \\
\hline
\end{tabular}

- The statistical significance coefficients (Sig.) for the dimensions of customs electronic business (electronic infrastructure - electronic business systems electronic information systems - electronic customs services - customs risk analysis management systems) are in order $(0.019,0.000,0.027,0.001,0.038)$, and all of them are less than 5 . This means that there is a significant effect of statistical significance from all dimensions of customs electronic business (electronic infrastructure - electronic business systems - electronic information systems - electronic customs services - customs risk analysis management systems) on the institutional performance of customs.

\subsection{Testing the Second Main Hypothesis}

There is a significant effect and a statistically significant relationship from the implementation of customs electronic business on the knowledge management of the Customs Authority of the Arab Republic of Egypt.

To test the previous hypothesis, the researcher used a multiple regression analysis, where the regression analysis was conducted through the dimensions of customs electronic business (Electronic infrastructure - electronic business systems - electronic information systems - electronic customs services - customs risk analysis management systems) as independent variables and knowledge management as a dependent variable.

It is evident from Table 5 that:

- The calculated (F) value of the analysis of variance (ANOVA) is 297.39 with a statistical significance level (Sig) equal to (0.000), i.e. less than 5, which means the quality of the model and the presence of a significant statistically significant effect of the independent variables on the dependent variable, that is, the presence of a significant effect of customs electronic business on knowledge management. 
Table 5. Regression analysis of the dimensions of customs electronic business on knowledge management.

\begin{tabular}{cccccc}
\hline & B & Std. Error & Beta & T & Sig. \\
\hline (Constant) & 0.964 & 0.101 & & 9.519 & 0.000 \\
Electronic Infrastructure & 0.215 & 0.039 & 0.258 & 5.484 & 0.000 \\
E-Business Systems & 0.003 & 0.051 & 0.003 & 0.055 & 0.956 \\
Electronic information systems & 0.405 & 0.051 & 0.481 & 7.882 & 0.000 \\
$\begin{array}{c}\text { Electronic customs services } \\
\text { Customs Risk Analysis }\end{array}$ & 0.162 & 0.045 & 0.190 & 3.593 & 0.000 \\
Management Systems & 0.006 & 0.034 & 0.007 & 0.174 & 0.862 \\
ANOVA(F) & $\mathbf{2 9 7 . 3 9}$ & (F)Sig & $\mathbf{0 . 0 0 0}$ & $\mathrm{R}^{2}$ & $\mathbf{0 . 7 8 6}$ \\
\hline
\end{tabular}

- The coefficients of statistical significance (Sig.) for the dimensions of customs electronic business (electronic infrastructure - electronic business systems electronic information systems - electronic customs services - customs risk analysis management systems) are in order (0.000, 0.000, 0.956, 0.000, 0.862), There are some dimensions less than 5., other values are higher than 0.05 , which means that there is a significant effect of statistical significance from the three dimensions of customs electronic business with a value less than 0.05 , They are (electronic infrastructure - electronic information systems services Electronic customs) on knowledge management, while there is no statistically significant effect of (electronic business systems - customs risk analysis management systems) on knowledge management, as the values of the significance (Sig) of these dimensions are greater than 5. It is 0.956 for electronic business systems, 0.862 Customs risk Analysis Management Systems.

\subsection{Test the Third Main Hypothesis}

There is a significant effect and a statistically significant relationship from the knowledge management of the Customs Authority of the Arab Republic of Egypt on the institutional performance of customs.

To test the previous hypothesis, the researcher used a multiple regression analysis, as well as calculating the coefficients through the SPSS program, to test the impact of the implementation of customs electronic business on knowledge management and the relationship between them, where the regression analysis was conducted through the dimensions of the Customs Authority of the Republic Arab Egypt (knowledge acquisition - knowledge storage - knowledge distribution - knowledge implementation) as independent variables on the institutional performance of customs as a dependent variable.

It is evident from Table 6 that: 
Table 6. Regression analysis: Dimensions of knowledge management on the institutional performance of customs.

\begin{tabular}{|c|c|c|c|c|c|}
\hline & B & Std. Error & Beta & $\mathrm{T}$ & Sig. \\
\hline (Constant) & 1.892 & 0.129 & & 14.690 & 0.000 \\
\hline Knowledge acquisition & 0.096 & 0.048 & 0.112 & 2.003 & 0.046 \\
\hline Knowledge Storage & 0.351 & 0.069 & 0.392 & 5.131 & 0.000 \\
\hline Knowledge Distribution & 0.330 & 0.063 & 0.415 & 5.207 & 0.000 \\
\hline Knowledge Implementation & 0.547 & 0.061 & 0.672 & 8.909 & 0.000 \\
\hline ANOVA(F) & 194.55 & (F)Sig & 0.000 & $\mathbf{R}^{2}$ & 0.658 \\
\hline
\end{tabular}

- The calculated (F) value of the analysis of variance (ANOVA) 194.55 with a level of statistical significance (Sig) equal to (0.000), i.e. less than 5. which means the quality of the model and the presence of a significant statistically significant effect of the independent variables on the dependent variable, that is, the presence of a significant effect It is statistically significant from the dimensions of knowledge management (knowledge acquisition - knowledge storage - knowledge distribution - knowledge Implementation) as independent variables on the institutional performance of customs.

- The coefficients of statistical significance (Sig.) for the dimensions of knowledge management (knowledge acquisition - knowledge storage - knowledge distribution - knowledge implementation) are in order (0.000, 0.046, 0.000, $0.000,0.000$ ), all of which are less than 0.05 This means that there is a significant effect with Statistical significance from all dimensions of knowledge management (knowledge acquisition - knowledge storage - knowledge distribution - knowledge a Implementation) on the institutional performance of customs.

\subsection{Test the Fourth Main Hypothesis}

There is a significant effect and a statistically significant relationship from the Customs Business Administration at the Customs Authority of the Arab Republic of Egypt on the institutional performance of customs through knowledge management as mediating variable.

To test the previous hypothesis, the researcher conducted a path analysis using the Structure Equation modeling (SEM), through the AMOS program version (23).

From Table 7 and Figure 2, it is clear that the level of statistical significance for all variables $(\mathrm{P})$ is less than 0.05 , that is, there is a statistically significant effect of electronic customs work on the institutional customs performance through knowledge management as a mediating variable. 
Table 7. Path analysis of the mediating variable (knowledge management).

\begin{tabular}{ccccccc}
\hline P & C.R. & S.E. & Estimate & & \\
\hline$* * *$ & 38.248 & 0.021 & 0.787 & $\begin{array}{c}\text { E-Business } \\
\text { Customs }\end{array}$ & $<--$ & $\begin{array}{c}\text { knowledge } \\
\text { management } \\
\text { institutional } \\
\text { performance }\end{array}$ \\
$* * *$ & 8.417 & 0.058 & 0.487 & $\begin{array}{c}\text { knowledge } \\
\text { management }\end{array}$ & $<---$ & institutional \\
& 3.916 & 0.052 & 0.202 & $\begin{array}{c}\text { E-Business } \\
\text { Customs }\end{array}$ & $<---$ & performance \\
\hline
\end{tabular}

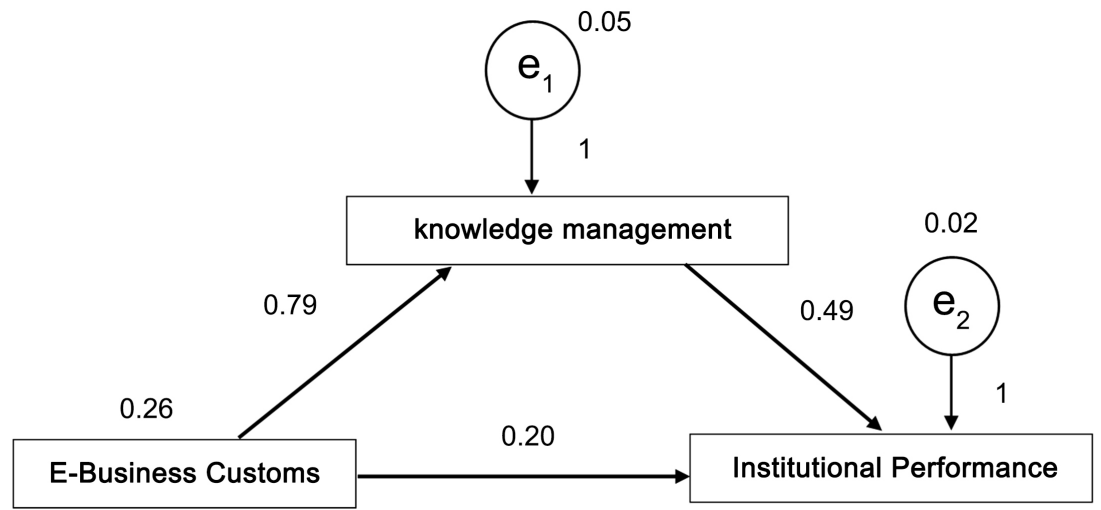

Figure 2. Path analysis of the mediating variable.

To verify the previous result, the table of model matching indicators (Goodness of model) is reviewed, where the table of the most important standard indicators for the quality of model matching indicators appears. (GFI) Goodness of fit index and Comparative fit index (CFI) should be greater than 0.8 , while the root mean square error of Approximation (RMSEA) should be less than 0.10.

It appears from Table 8 that the results are statistically significant, and the results indicated that the modified or weighted (chi) 2 statistic with degrees of freedom is 2.31, in addition to the Goodness of fit index (GFI) of 1 and the Goodness of fit index (GFI) of 1. The Adjusted Goodness of Fit Index 1 and the Comparative fit index (CFI) are acceptable indicators because they are good for comparing the quality of the measures with the difference in sample size from one study to another. The Root Mean Square Error of Approximation (RMSEA) is 0.0908 , all indices are acceptable.

\section{Results}

- There is a significant effect and a statistically significant relationship between the adoption of customs electronic business and the institutional performance of the Customs Authority of the Arab Republic of Egypt.

- There is a significant effect and a statistically significant relationship from the adoption of customs e-business on the knowledge management of the Customs Authority of the Arab Republic of Egypt. 
Table 8. Model fit index results.

\begin{tabular}{cc}
\hline Value & Model Fit Index \\
\hline 2.31 & Chi-square/df \\
1 & GFI \\
1 & CFI \\
0.0908 & RMSEA
\end{tabular}

- There is a significant effect and a statistically significant relationship from the knowledge management of the Customs Authority of the Arab Republic of Egypt on the institutional performance of customs.

- There is a significant effect and a statistically significant relationship from the knowledge management of the Customs Authority of the Arab Republic of Egypt on the institutional performance of customs through knowledge management as a mediating variable.

\section{Recommendations}

Based on the results of the current study, this study presents a number of recommendations, the most important of which are:

- paying more attention to electronic custom services, improving the relationship with customers and working to build and develop a successful strategy to stimulate e-business applications.

- work on activating customs risk analysis management systems for their great impact on upgrading customs work and facilitating the legitimate trade movement and increasing confidence in the trade business as a whole, which has the greatest impact on upgrading the national economy.

- should improve the electronic infrastructure in all the work of the Customs Authority and providing all the elements related to information technology necessary for the digital transformation of customs and facilitating electronic business.

- work on the application of electronic business systems and electronic information systems in an integrated and sound manner and the availability of all the necessary elements to activate the integrated electronic system for the customs authority to simplify the procedures and facilitate work for the beneficiaries of customs services

- pay more attention to knowledge management and its steps from process of gaining knowledge and ensuring the availability of all information necessary to make decisions and simplify work for the employees of the Customs Authority.

\section{Conclusion}

Challenges facing the customs authority institutions have continuously changed 
the management system of customs in different countries from long times ago. Interactive and user friendly e-Customs services which facilitate the preparation, filing, tracking and storage of customs declarations, among other functions, can help to reduce costs and improve efficiencies in cross-border supply chains. Design and implementation of e-Customs services need to be driven by tangible benefits for the private sector, including facilitating export procedures, improving flexibility when working with customs, reducing the need to re-enter any customs data during the declaration processes, and enabling a seamless flow of data between the parties involved. This study aimed to investigate the impact of electronic customs business on the institutional performance of the Customs Authority in the Arab Republic of Egypt through knowledge management as a mediator variable. The study reached a set of results, the most important of which is: there is a significant and statistically significant effect of electronic customs work on the institutional performance. Based on the results of the study, the study concluded with a set of recommendations, the most important of which is: paying more attention to electronic custom services, improving the relationship with customers and working to build and develop a successful strategy to stimulate e-business applications.

\section{Conflicts of Interest}

The authors declare no conflicts of interest.

\section{References}

[1] Karampour, A., Sharifi, K. and Safabakhsh, Sh. (2012) A Model for Assessing the Impact of Resource-Based Approach Based on Cost Leadership Strategy on Export Performance in Non-Metallic Minerals Industry. Business Administration (Management Faculty of Tehran University), 4, 113-128.

[2] Bordonaba-Juste, V., Lucia-Palacios, L. and Polo-Redondo, Y. (2012) The Influence of Organizational Factors on E-Business Use: Analysis of Firm Size Marketing. Intelligence \& Planning, 30, 212-229. https://doi.org/10.1108/02634501211211984

[3] Egyptian Customs Authority Website. https://www.customs.gov.eg/

[4] Granqvist, M., Hintsa, J., Lazarescu, M. and Tsikolenko, V. (2010) E-Customs Study: Private Sector Views on Potential Benefits of Further Electronic Customs Developments in Switzerland. Cross-Border Research Association, Lausanne.

[5] Salamzadeh, Y., Nejati, M. and Heidaripourafshar, Y. (2015) An Investigation into the Impact of E-Customs on Stretching Strategic Thinking: Case Study Islamic Republic of Iran Customs Administration (IRICA). Journal of Entrepreneurship, Business and Economics, 3, 105-139.

[6] Shirsavar, H.A. and Shirinpour, M. (2016) The Effect of Electronic Customs Administration on Facilitating the Export Activities of Export Companies Based in Gilan, Iran. Intellectual Economics, 10, 114-121. https://doi.org/10.1016/j.intele.2017.03.004

[7] Alipour Shirsavar, H.R., Mahdi, M.S., Varkaroud, K., Khandani, H. and Hosseini, M. (2013) Practical Implementation of Electronic Customs to Increase Efficiency and Administrative Health Using RFID Technology, Quality Support and Engineering Management. In: Aqajani, H.A., Gul, M., Anne, H.M., et al., Eds., Paper on 
RFID Technology at a Glance, 1-12.

[8] Manivannan, S. (2009) Security and Trust in E-Business: Problem and Prospects.

[9] AL-A'Wasa, S.I. (2017) Impact of E-Business Application of Customs on Achieving Strategic Objectives: An Empirical Study on the Jordanian Customs Department. Jordan Journal of Business Administration, 14, 339-366.

[10] Aqajani, H.A., Gul, M., Anne, H.M. and Rahmanqoli (2010) The Advantage of E-Commerce Implementation of Customs. Ministry of Economic Affairs and Finance, Conference for World Customs Day, 1-11.

[11] Hasanzadeh, A. (2007) Examining the Role of Electronic Customs in Facilitating Exports. Journal of Business Research, 43.

[12] Salamzadeh, Y., Nejati, M. and Heidaripourafshar, Y. (2015) An Investigation into the Impact of E-Customs on Stretching Strategic Thinking, Case Study Islamic Republic of Iran Customs Administration (IRICA). Journal of Entrepreneurship, Business and Economics, 3, 105-139.

[13] Al-Hayek, N.A. (2016) The Impact of Implementing Governance on Improving Performance in Governmental Institutions (Case Study of the General Directorate of Syrian Customs). Syrian Arab Republic Ministry of Higher Education, Syrian Virtual University, Damascus.

[14] World Bank (2021) Annual Report 2021: From Crisis to Green, Resilient, and Inclusive Recovery. World Bank, Washington DC.

https://www.worldbank.org/en/about/annual-report

[15] Orlova, L.V., Afonin, Y.A. and Voronin, V.V. (2015) Talent Management and Knowledge: Theory, Methodology, Models. Review of European Studies, 7, 75-82. https://doi.org/10.5539/res.v7n9p75

[16] Payal, R., Ahmed, S., Roma Mitra, D. (2019) Impact of Knowledge Management on Organizational Performance: An Application of Structural Equation Modeling VINE. Journal of Information and Knowledge Management Systems, 49, 510-530. https://doi.org/10.1108/VJIKMS-07-2018-0063 